\title{
Defining agency and its scope
}

\section{Deborah A. DeMott, Duke University*}

\section{Forthcoming in Comparative Contract Law: A Tale of Two Legal Systems (Martin Hogg \& Larry A. DiMatteo eds., Oxford Univ. Press 2015)}

\section{$1 \quad$ Introduction}

Justice Felix Frankfurter once observed that "to say that a man is a fiduciary only begins analysis; it gives direction to further inquiry. To whom is he a fiduciary? What obligations does he owe as a fiduciary?"1 Much the same point can be made about the statement that a person is an agent. That a person acts as a principal's agent does not mean that agency law-including the fiduciary duties it imposes_-necessarily governs the entirety of the relationship between agent and principal. An agent may have rights defined by contract that the agent may exercise, distinct from the agent's fiduciary duties to the principal, while, separately, the principal may consent to conduct by the agent that would otherwise breach the agent's fiduciary duties. And the agent's duties to the principal may be delimited by time, owing the principal lesser or no duties before the agency relationship begins and once it ends. More generally, whether any particular actor should be characterized as an agent in relationship to another person-the "principal" if the actor is an agent - is not always a straightforward question. If the parties' relationship is one of agency

\footnotetext{
*I served as the Reporter for the American Law Institute's Restatement Third of Agency, published in final form in 2006. I presented drafts of earlier versions of this Chapter at the $38^{\text {th }}$ Annual Workshop on Commercial and Consumer Law, in a public lecture at Queen's University, and at the conference "Transatlantic Perspectives on Commercial Law." Thanks to all who commented.

${ }^{1}$ SEC v. Chenery Corp., 318 US 80, 85-86 (1943).
} 
within the common-law definition, the agent's conduct affects the principal's legal relations with third parties when the agent acts with actual or apparent authority. Additionally, at least portions of the agent's relationship to the principal are fiduciary in character. This triggers specific requisites for effective consent by the principal to conduct that would otherwise breach the agent's duties when the conduct is within the scope of the agency relationship and not excluded or sheltered from its demands by rights, distinct from the relationship, held by the agent.

As this Chapter demonstrates, whether a relationship amounts to one of common-law agency matters in many contexts, so widely so that the Chapter only samples recent cases from the United States that test the presence or absence of agency relationships. Albeit disparate in context and stakes, the cases illustrate the broad applicability of the common-law definition. It is well-established that an agency relationship is "the fiduciary relationship that arises when one person (a 'principal') manifests assent to another person (an 'agent') that the agent shall act on the principal's behalf and subject to the principal's control, and the agent manifests assent or otherwise consents so to act.", The fiduciary character of the relationship is constitutive of agency; that is, if in a particular relationship an actor owes no duty of loyalty to anyone, the law in the United States is clear that the relationship, whatever it may be, is not one of agency. Likewise constitutive are the principal's power or right to control the agent and the agent's capacity to affect the principal's legal relations with third parties.

By characterizing an agent as person who "acts on behalf of" a principal, agency law positions the agent as the principal's representative for purposes of legally-salient interactions with third parties and facts about the world. An agent serves as an extension of the principal, and not, as is true of some fiduciaries, a substitute charged to act in the best interests of the

\footnotetext{
${ }^{2}$ Restatement (Third) of Agency $\S 1.01$.
} 
beneficiary of the relationship. ${ }^{3}$ Thus, the principal's continuing existence is requisite to an ongoing agency relationship. ${ }^{4}$ A principal has an ongoing power or right of control over the agent, with the capacity to furnish interim instructions to the agent; the agent's duty is to interpret instructions received from the principal faithfully, as the agent reasonably understands the principal would wish at the time the agent determines how to act. ${ }^{5}$ And an agent's conduct directly affects the principal's legal relations with third parties when the agent acts with actual or apparent authority. Thus, the agent's role does not so much substitute for the principal as it elongates the principal externally, a characterization grounded in the principal's continuing powers of control; the direct impact the agent's actions carry for the principal; and the agent's duty to interpret instructions received from the principal in light of the principal's present wishes. ${ }^{6}$

Despite their theoretical and practical significance, the lines of demarcation between an

\footnotetext{
${ }^{3}$ This point and its implications are elaborated at length in Deborah A DeMott, 'The Fiduciary Character of Agency and the Interpretation of Instructions' in Andrew S Gold \& Paul B Miller (eds) Philosophical Foundations of Fiduciary Law (OUP 2014) hereinafter DeMott, 'Fiduciary Character').
}

4 Restatement (Third) of Agency § 3.07 (2) (death of individual principal terminates agent's actual authority, effective when agent or third party has notice of principal's death); $\$ 3.07$ (4) (cessation of existence of principal that is not an individual, or commencement of process that will lead to cessation, terminates agent's actual authority in absence of law providing otherwise). Apparent authority terminates when it is no longer reasonable for the third party with whom the agent deals to believe that the agent continues to act with actual authority. Id § 3.11.

${ }^{5}$ Kent Greenawalt, Legal Interpretation (OUP 2010) 220-7; DeMott, 'Fiduciary Character' (n 3 ) 322.

${ }^{6}$ Of course, an agent may occupy an additional fiduciary role, such as trusteeship, that requires service as a substitute. Restatement (Third) of Agency § 1.04(10)(defining "trustee" as "a holder of property who is subject to fiduciary duties to deal with the property for the benefit of charity or for one or more persons, at least one of whom is not the sole trustee" and "agent-trustee" as "a trustee subject to the control of the settlor or one or more beneficiaries"). 
agent's fiduciary duties and the larger set of rights and duties between agent and principal are relatively unexplored. Depending on the compass of an agent's fiduciary duties, the agent may or may not be privileged to take actions that impair the principal's interests. If such an action falls within the scope of the agent's fiduciary duties, it breaches the agent's duty unless the principal consents to it. To be effective, the principal's consent must be focused on either a specific act or a type of act that may reasonably be expected to occur. ${ }^{7}$ The consent's effectiveness also requires that the agent deal fairly and in good faith with the principal and disclose to the principal all material facts that the agent knows or should know would reasonably affect the principal's judgment. ${ }^{8}$ Thus, in obtaining consent, the agent acts subject to constraints that are themselves the consequence of the agent's fiduciary position. But such constraints are inapplicable when the agent's act is outside the scope of the agency, that is, when the act is distinct from the actions that the agent has undertaken to perform as the principal's representative.

The larger theoretical stakes are significant. These issues and the cases in which they surface furnish intriguing applications for the terminology, concepts, and analysis developed by recent scholarship concerning the nature of legal rules and the relative ease with which parties to a given transaction or relationship may alter them. An agent's fiduciary duties to the principal are often characterized as default rules, set at the categorical level and imposed by the law when a particular relationship falls within the category of "agency." Thus, the content of an agent's

\footnotetext{
${ }^{7}$ Restatement (Third) of Agency $\S 8.06(1)(2006)$

${ }^{8} I d$.

'Mariana Pargendler, 'Modes of Gap Filling: Good Faith and Fiduciary Duties Reconsidered' (2008) 82 Tul L Rev 1315, 1344. Although beyond the scope of this paper, fiduciary duties are best understood as imposed by the law although the parties' relationship is consensual. Scholars are divided on this question of categorization, which is the subject of an extensive literature.
} 
fiduciary duties does not represent a "tailored" approximation of the terms for which a particular principal and agent might have contracted..$^{10}$ Legal theorists characterize fiduciary duties as instances of "sticky" default rules, ones that are more difficult to alter. ${ }^{11}$ The legal standard by which they may be abrogated or varied is set at a higher level than is the case for other default rules. ${ }^{12}$ Prior scholarship does not, however, address issues that arise when the question is demarcating the boundary between an agent's fiduciary duties and other rights and duties as between agent and principal.

This Chapter identifies two distinct determinations: (1) the scope of the role in which an agent's actions will carry legal consequences for the principal; and (2) consent by the principal to action by the agent within that scope that would otherwise breach the agent's fiduciary duties. This distinction eludes simple contractualist accounts of agency and fiduciary obligation more generally. The legal doctrines that underlie these distinctions are instances of "altering rules," that is, the necessary and sufficient conditions to vary a default rule. ${ }^{13}$ The scope of an agent's role or undertaking is established by agreement between agent and principal. A legally-effective agreement may encompass a range of possible outcomes that are not fully specified and may be legally effective although one party does not disclose material information to the other. ${ }^{14}$

\footnotetext{
${ }^{10}$ Id at 1320. On "tailored" versus "untailored" rules that fill out terms in parties' contracts, see Ian Ayres \& Robert Gertner, 'Filling Gaps in Incomplete Contracts: An Economic Theory of Default Rules' (1989) 99 Yale L J 87, 91-92.
}

${ }^{11}$ See Brett McDonnell, 'Sticky Defaults and Altering Rules in Corporate Law' (2007) 60 SMUL $\operatorname{Rev} 383,384$.

${ }^{12}$ See Pargendler (n 9) 1343.

${ }^{13}$ For the "altering rule" terminology, see Ian Ayres, Menus Matter, (2006) 73 U Chi L Rev 3.

${ }^{14}$ See Restatement (Second) of Contracts $\$ 3$ (1981)(defining "agreement" as "a manifestation of mutual assent on the part of two or more persons" and a "bargain" as "an agreement to exchange 
However, a principal's consent to conduct that would otherwise breach a fiduciary duty requires specificity. It is comparable to a victim's consent to an actor's commission of an intentional tort, which is not effective unless it represents "willingness in fact" that the tortious conduct occur. ${ }^{15}$ At least for the United States, the salience of a tort-law standard is unsurprising because breach of fiduciary duty is conventionally defined to be tortious conduct. ${ }^{16}$

Moreover, "consent" in this sense is significantly different from the more diffuse term, "consensual," as well as from the operation of consent in transactional applications of agency law. Agency is a species of consensual relationship, one not mandated by the law, comparable in this respect to many other relationships that persons may choose to have with each other. ${ }^{17}$ But consenting to have such a relationship is not equivalent to manifesting willingness in fact to be affected by all acts that may be committed by the other party to the relationship. Separately, in the transactional realm, an agent's ability to create contractual liability that binds the principal to a third party with whom the agent interacted is often grounded in the principal's consent, via either a conferral of actual authority on the agent or the appearance of authority on which a third

promises or to exchange a promise for a performance or to exchange performances"). The fact that terms are missing from an agreement or are left for later agreement does not defeat formation of a contract if "the actions of the parties...show conclusively they intended to conclude a binding agreement" and the court is able "to attach a sufficiently definite meaning to the bargain." Id. § 33, cmt. a.

${ }^{15}$ Restatement (Second) of Torts $\S 892(2)$ (1979).

${ }^{16} \mathrm{Id} \S 874$. For further discussion of section 874 and the implications of treating breach of fiduciary duty as a tort, see Deborah A. DeMott, 'Breach of Fiduciary Duty: On Justifiable Expectations of Loyalty and Their Consequences' (2006) 48 Ariz L Rev 925.

${ }^{17}$ Marriage, contracts, and bailments are other examples of legally-distinct relationships that are consensual. 
party relies. ${ }^{18}$ Although the principal's "consent" can fairly be characterized as "the core of any normative account" of the transactional dimensions of agency doctrine, ${ }^{19}$ it operates not as transaction-by-transaction consent, but as an advance expression of the principal's will (or what reasonably so appears to the third party) that thereafter "exists in the background during the agent's negotiations" with a third party. ${ }^{20}$ Once manifested, such consent continues to lurk, sufficing later to bind the principal to transactions within its scope albeit the principal would then prefer not to be bound. As the Chapter demonstrates, consent in the agency context may be defined to require more or less specificity so that definitions differ markedly in the level of generality at which they operate.

Legal taxonomy aside, requiring particularized (and not "lurking") consent from a principal to conduct that would otherwise contravene the agent's fiduciary duties is consistent with the stickiness of fiduciary duty as a legally-imposed and categorical default. Loyalty to a principal's interests when action is taken on the principal's behalf is likely to correspond to the expectation of most principals, while a principal's vulnerability to disloyal action by an agent is an underlying justification for the imposition of fiduciary duty on the agent. ${ }^{21}$ The requirement of particularized consent also recognizes that from a principal's standpoint, an agent's disloyalty

\footnotetext{
${ }^{18}$ See Gerard McMeel, 'Philosophical foundations of the law of agency' (2000) 116 LQR 387, 389.

${ }^{19}$ Id at 410.

${ }^{20}$ See Danny Busch \& Laura Macgregor, 'Introduction' in Danny Busch \& Laura Macgregor (eds), The Unauthorised Agent 1, 2 (OUP 2009).

${ }^{21}$ For these points in the corporate-law context, see McDonnell (n 11) 414-16. On the principal's vulnerability to the agent, see Restatement (Third) of Agency $\S 8.01$, cmt b (noting "the vulnerability that any relationship of agency creates by exposing the principal's property or interests more generally to the risk of self-interested action by the agent").
} 
betrays the principal's interests and is not simply an occasion for disappointment, comparable to a generic breach of contract. Relatedly, the principal's entitlement to loyalty from the agent operates independently of whether the agent has fulfilled other duties owed to the principal, including those defined by contract between principal and agent. ${ }^{22}$

The remainder of this Chapter applies these general points to concrete examples. Section 2 opens with recent cases that illustrate how courts in the United States apply the common-law definition of agency and how cases applying agency law treat the parties' own statements about the nature of their relationship. Section 3 focuses on the scope of an agent's role, prefaced by the basic point that contractual attempts to limit an agent's authority or the legal consequences of the agent's conduct for the principal are not binding on third parties who are unaware of such limitations. Section 3 then examines settled examples of actions that an agent may take that are acknowledged to fall outside the scope of an agency role and thus beyond the boundary of the agent's fiduciary duties to the principal. The section next examines recent cases that turn on delineating the scope of an agent's role and duties in the context of auctions for art objects. Of intrinsic interest, these cases are valuable more generally because the application of standard agency-law doctrine in this setting is less well established than in many others. Art markets (like the residential real estate context that features in Section 4) are distinctive in many ways, including extensive and customary use of non-employee intermediaries. Section 4 focuses on instances of a principal's consent (or purported consent) to action by an agent that would otherwise breach the agent's fiduciary duties, including several illustrations involving transactions in residential real estate. Section 4 also examines, more briefly, end-of-relationship

\footnotetext{
${ }^{22}$ See Rebecca Lee, 'In Search of the Nature and Function of Fiduciary Loyalty: Some Observations on Conaglen's Analysis' (2007) 27 Oxford J Leg Stud 327, 332.
} 
agreements in which a principal consents to release claims against an agent. Section 5 contrasts the legally operative consequences of "consent" with "agreement" and argues that these consequences parallel other aspects of basic agency-law doctrine.

\section{$2 \quad$ Defining agency}

The elements of the standard definition of common-law agency are constitutive of an agency relationship with the consequence that the absence of any element from a particular relationship means that it is not an agency relationship. The standard definition characterizes a relationship between two persons as one of agency only when one person or actor is a fiduciary, acts subject to the control of the other person, and acts as that person's representative (or on the person's behalf). ${ }^{23}$ Applying the standard definition is often unproblematic, at least in part because the functions served by some agents are so settled that characterizing the relationship seems obvious. It may thus be surprising that outcomes in significant cases continue to turn on contested applications of the basic definition; but given the variety of relationships to which the definition of agency may potentially apply, perhaps the persistence of definitional disputes is unsurprising.

\subsection{Definitional elements applied}

For starters, in the public-law context, in Hollingsworth v. Perry the Supreme Court of the United States held that proponents of a California ballot initiative amending the state's constitution to eliminate the right of same-sex couples to marry did not have standing to appeal an order from a federal district court finding the initiative unconstitutional (under the federal constitution) after the state's elected officials declined to defend the amendment. ${ }^{24}$ Standing for federal-court purposes is limited to parties who have suffered a concrete and particularized

\footnotetext{
${ }^{23}$ See text accompanying $\mathrm{n} 2$.

${ }^{24} 133$ S Ct 2652 (2013).
} 
injury, which the Court held was not true of the proponents, who had no personal stake in the initiative once the voters approved it. ${ }^{25}$ Although the proponents characterized themselves as agents of the state, they were not, in the Court's assessment; the proponents neither held official designations or appointments authorizing them to defend the state's interests, nor were they agents of the state's people because "the most basic features of an agency relationship are missing here." ${ }^{26}$ The proponents "answer to no one; they decide for themselves, with no review, what arguments to make and how to make them." 27 Thus, the proponents lacked a principal in the agency-law sense with rights or powers of control, whether exercised through an initial statement of authority or through interim instructions. Moreover, the proponents "owe nothing of the sort" resembling a fiduciary obligation to the people of the state, ${ }^{28}$ their litigation strategy as a consequence was not bounded by "the need to take cognizance of resource constraints, changes in public opinion, or potential ramifications for other state priorities." 29 Thus, the absence of two constitutive elements of common-law agency established that the proponents lacked standing. ${ }^{30}$

Away from the high stakes of constitutional litigation, the constitutive quality of the common-law definition of agency shapes judicial decisions across the board. One recent

\footnotetext{
${ }^{25} 133 \mathrm{~S} \mathrm{Ct}$ at 2663.

${ }^{26} 133 \mathrm{~S} \mathrm{Ct}$ at 2666.

${ }^{27} 133 \mathrm{~S} \mathrm{Ct}$ at 2667.

${ }^{28} \mathrm{Id}$.

${ }^{29} \mathrm{Id}$.
}

${ }^{30}$ Beyond the scope of this Chapter are whether the Court's construction of standing doctrine is justifiable and whether the voter-initiative process in California and twenty-six other states warrants a test for proponents' standing that departs from the requisites of common-law agency. See 133 S Ct 2675 (arguing that majority "fails to grasp or accept ... the basic premise of the initiative process...")(Kennedy, J dissenting). 
transactional example stems from the world of online sales of travel accommodations. In Johnson v. Priceline.com, Inc., the defendant was an online vendor that used, among its business models, a service termed "Name Your Own Price" that invited consumers to " bid"” for hotel rooms. ${ }^{31}$ Users of this service did not designate a particular hotel but instead indicated the dates for which they needed accommodations and the neighborhood or geographic area they desired, plus the minimum "star"” quality they deemed acceptable. Users then placed bids at the minimum price they were willing to pay; after searching its online inventory (which was proprietary) Priceline notified the user whether a bid had been accepted and, if so, the hotel for which a reservation had been booked. However, Priceline did not disclose to its users that it would not accept a bid unless its inventory enabled it to satisfy the bid at a rate lower than the bid price, with the differential retained by Priceline as profit in addition to its stated (and disclosed) service fee.

The plaintiffs in Johnson argued that Priceline represented itself as a travel agent and, as their agent, breached its fiduciary duty to them by retaining the bid-rate differential without disclosing this practice to them. Of course, an agent commits a garden-variety breach of fiduciary duty by acquiring a material benefit in connection with a transaction conducted on the principal's behalf without the principal's consent. ${ }^{32}$ Examining these facts against the elements of the common-law definition of agency, the court held that Priceline was not an agent of users of its "Name Your Own Price" service and thus did not owe them an agent's fiduciary duty. In the court's analysis, it was fatal to the plaintiff's agency claim that, once a customer submitted a

\footnotetext{
${ }^{31} 711$ F 3d 271 (2d Cir 2013).

${ }^{32}$ Restatement (Third) of Agency $\S 8.02$. Section 4 discusses distinctions between disclosure to a principal and effective consent by the principal.
} 
bid, the customer thereafter "retained no authority over the manner in —or the price for-which the reservation will be procured," thereby depriving the customer of any "right of interim control..."33 Johnson relies on the well-established difference between a principal's interim control over an agent and "delimit[ing] the choices that [a] service provider has the right to make," 34 which does not constitute "control" for agency-law purposes. Additionally, and more factually contingent, the court highlights the practical fact that "there is no "interim"" in Name Your Own Price transactions, which are effected in "nearly instantaneous" manner, comparable to a non-online intermediary "rifling through" its inventory to locate conforming goods that a customer has stated a willingness to buy at a specified price. ${ }^{35}$

\subsection{The parties' own characterization}

How two parties characterize their own relationship raises separate questions. As noted above, agency is a consensual relationship grounded in a manifestation of assent from the principal and the agent's counterpart manifestation of assent or consent. But courts in most if not all jurisdictions in the United States would likely also agree with the Restatement (Third) proposition that "[w]hether a relationship is characterized as agency in an agreement between parties or in the context of industry or popular usage is not controlling." ${ }^{36}$ The parties' own characterization of their relationship — as agency or not-agency — may be relevant at least as an evidential matter to a court's determination but is not dispositive.

\footnotetext{
${ }^{33} 711 \mathrm{~F} 3 \mathrm{~d}$ at 278.
}

${ }^{34}$ Id at 6, quoting Restatement (Third) of Agency $\S 1.01$, cmt f.

${ }^{35} I d$. Alternatively, the court analogizes "Name Your Own Price" customers to bidders at a conventional auction. In a limited way an auctioneer may become an agent of a bidder as well as the consignor, see section 3.2 .

${ }^{36}$ Restatement (Third) of Agency $§ 1.02$. 
However, even when the assertion of an agency relationship is made by a third party, some jurisdictions focus on determining the principal's will or intention and accord weight to disclaimers of agency. In New Millennium Consulting, Inc. v. United Healthcare Services, Inc., a federal court assessed the significance under state (Minnesota) law of a disclaimer of agency status in a dispute between a supplier of contingent labor and a centralized management company that assisted its customers in procuring and managing contingent workers in information-technology fields. ${ }^{37}$ Following the management company's insolvency, the labor supplier sued one of the management company's customers to recover outstanding amounts due. The standardized agreement between the customer and the management company stated that the parties " intend to create an independent contractor relationship and nothing contained in this agreement shall be construed to make either Customer or [management company] ... principals, agents, or employees of the other ....” The agreement also provided that the management company would be solely responsible for paying suppliers, but only once it received payment from the customer. ${ }^{38}$

To be sure, the court might have read the non-intention language narrowly, as disclaiming only potential constructions of the agreement itself, as opposed a broader reading encompassing the court's application of the law to its factual determinations. Instead, the court embraced the challenge presented by Minnesota precedents, which "focus[] on the will of the principal in determining agency," even in cases involving third-party claims. Minnesota cases treat language like that in New Millennium as effective to show that the purported principal did

\footnotetext{
${ }^{37} 695$ F3d $854\left(8^{\text {th }}\right.$ Cir 2012).

${ }^{38} 695 \mathrm{~F} 3 \mathrm{~d}$ at 856.
} 
not consent to a relationship of agency. ${ }^{39}$ Arguably mitigating or vitiating its emphasis on the import of written indicia of the principal's will, the Eighth Circuit observed that the plaintiffs did not claim that the management company had apparent authority to act on behalf of the customer, that is, that they reasonably understood manifestations of the customer to mean that the management company acted as the customer's agent in dealings with the plaintiffs. ${ }^{40}$ Additionally, the court noted that the customer and the management company "never disguised anything about their relationship...and the [labor] suppliers knew exactly who they were contracting with;" 41 and on its facts the relationship between the customer and the management company lacked indicia of agency, in particular because the customer asserted no control over the management company. ${ }^{42}$ Thus, although the New Millennium court duly cited applicable state-law doctrine stressing the principal's will as determinative of the existence of an agency relationship, the court's qualifications and cautions imply an overall stance not so different in substance from other jurisdictions.

\section{The scope of an agency relationship}

One challenge for consensual accounts of agency is the question: "consent to what?" Parties' ability to define the scope of an agency relationship reflects consensual understandings of the relationship's boundaries relative to agency law. However, parties within the confines of an agency relationship lack the power, through contractual disclaimers or internal agreements, to reshape agency's legal consequences that stem from the agent's dealings with third parties. This

${ }^{39} 695$ F.3d at 859, citing Mikulay v. Home Indem Co, 449 NW2d 464, 467 (Minn Ct App 1989).

${ }^{40}$ See Restatement (Third) of Agency $§ 3.03$.

${ }^{41} 695$ F3d at 859.

${ }^{42} 695$ F3d at 859-60. 
limitation underlies the robust doctrine of apparent authority, mentioned above, because it disallows restrictions on an agent's authority from undercutting the reasonable beliefs of third parties who deal with the agent on the basis of the principal's manifestations of the extent or even the existence of the agent's authority, when those restrictions are unknown to the third party. This basic point about the reach of agency doctrine also underlies the principal's liability when the agent does business in a manner consistent with customary industry practice using means that the principal claims not to have authorized, when the agent reasonably believes the principal nonetheless wishes the agent to follow customary practice. ${ }^{43}$ And, when the customary practice happens to be illegal, the principal's internal restrictions on the agent's authority do not necessarily defeat the principal's liability. ${ }^{44}$

\subsection{Inclusions and exclusions from scope of relationship}

In contrast, as between themselves, the parties to an agency relationship may define its scope through inclusion and exclusion. In many standard instances of agency relationships, an agent has rights that the agent may exercise, distinct from the agent's fiduciary duties to the principal, although by exercising the right the agent impairs the principal's interests. Thus, an agent may have the right to assert a lien over property of the principal to assure payment of agreed-to compensation for the agent's services. ${ }^{45} \mathrm{~A}$ securities broker who lends funds to a client to

\footnotetext{
${ }^{43}$ Restatement (Third) of Agency $\S 2.02 \mathrm{cmt} \mathrm{f}$.

${ }^{44}$ See Chicago Title Ins Co v. Washington Office of Ins Comm'r, 309 P3d 372 (Wash 2013)(large title insurer, having authorized local title company to solicit business on its behalf, also impliedly authorized it to do acts necessary and customary toward larger objective of landing business for title insurer; local title company, contrary to statutory and administrative prohibitions but consistently with pervasive industry practice, made many gifts to real-estate middlemen, binding title company despite language in agreement limiting authority to acts expressly designated therein).

${ }^{45}$ See Restatement (Third) of Agency $\S 8.01, \mathrm{cmt} \mathrm{c}$.
} 
complete transactions through a margin account becomes the client's creditor and holds securities in the account as a pledgee; in acting as a lender to its principal, the client, the broker is not acting as an agent. ${ }^{46}$ If a broker liquidates a margin account as permitted by the account agreement when the account becomes under-margined, the broker's action may be deleterious to the client but lies beyond the scope of any fiduciary duty the broker owes the client as its principal. $^{47}$

An agent may also exercise contractually-conferred rights that cut even closer to its agency relationship with the principal. In Palm Bay International, Inc. v. Marchesi de Barolo, S.P.A., an Italian wine producer entered into an agreement with two individuals, appointing them its exclusive sales agents in the United States. ${ }^{48}$ The individuals' obligation under the agreement was to select importers, distributors, and wholesalers; they appointed a company (Palm Bay) of which they were the sole owners, which entered into a contract for the exclusive right to import the producer's wine into the United States. Disputes arose when wine sold by Palm Bay to a restaurant chain proved defective and the agents directed Palm Bay to set off amounts it owed the producer against monies it had paid the restaurant chain for the bad wine. The court held that the setoff, to which the principal protested, did not breach the agents' fiduciary duty to the principal because the scope of their agency encompassed only the appointment of the importer, Palm Bay, not their instruction to it directing the set-off. ${ }^{49}$ Put differently, the agreement under which the producer appointed its individual agents was separate from Palm Bay's contract with it

\footnotetext{
${ }^{46}$ See, e.g., Walston \& Co. v. Miller, 410 P2d 658 (Ariz 1966).

${ }^{47}$ See, e.g., First Am Disc Corp v. Jacobs, 756 NE2d 273, $281-82$ (Ill App Ct 2001).

${ }^{48}$ Palm Bay Int'l, Inc v. Marchesi de Barolo SPA, 796 F Supp 2d 396 (SDNY 2011).

${ }^{49}$ Id. at * 9 .
} 
as importer, not a component of one integrated agreement all within a fiduciary ambit. ${ }^{50}$

\subsection{Art auctions and agency relationships}

Auctions of art objects illustrate both the operation of agency doctrine and the efficacy of parties' limits on the scope of agency relationships. An owner of a work of art who consigns it for sale to an auction house becomes a principal in a relationship in which the auction house acts as the consignor's agent. Conventionally the terms of their relationship are set forth in a written consignment agreement, which provides that the auction house will offer the consigned property for sale at auction. A consignment agreement is often made subject to the terms of the auction house's standard contracts with purchasers, which are its conditions of sale and its limited warranty or guarantee agreement. If the consignor sets a reserve price- the confidential minimum price the consignor will accept — the auctioneer may "bid up" to that amount by placing bids on the consignor's behalf. ${ }^{51}$ Auction-house contracts also recognize that the auction house may accept bids in advance ("order bids") on behalf of absentee bidders and place them on the absentee bidders' behalf. ${ }^{52}$ In a limited way, this practice situates the auction house in a classic (if limited) position of dual agency, through which it represents both its consignor and the absentee bidder on whose behalf it places an order bid. ${ }^{53}$ A skillful auctioneer holding an order

\footnotetext{
${ }^{50}$ On setoff generally, see Restatement (Third) of Agency $\S 6.06$. Typical setoff disputes involve amounts that the agent owes the third party or the third party owes the agent, and that the third party and the principal owe each other. In Palm Bay, the amounts setoff were owed by the importer to the principal but the importer, as a third party for purposes of agency doctrine, was controlled by the agent; no amounts owed to or by the agents were involved.

${ }^{51}$ See John H. Merryman et al, Law, Ethics \& the Visual Arts ( $5^{\text {th }}$ edn Kluwer Law Intl 2007) 1028 (Sotheby's Conditions of Sale and Terms of Guarantee (2001)).

${ }^{52}$ Id. at $1004-05$.

${ }^{53}$ The court's analysis in Johnson did not acknowledge this possibility. See 2013 WL 1223326 at * 7 (stating that Priceline's customers who bid in "Name Your Own Price" system "do not 
bid, aware of the fiduciary problem, would calculate in advance the price at which to open bidding plus the amount of subsequent bid increments, so that the amount of the order bid is reached "in the book" and not by a bidder in the auction room. Otherwise, the auctioneer has not discharged the house's duty to the absentee bidder because bidding in the room has outpaced the order bid. Of course, a bidder in the room could then outbid the absentee bidder at the next higher price interval. ${ }^{55}$

The ensemble of agreements linking consignor, auction house, and successful bidder may expressly permit action by the auction house that is either injurious to the consignor or inconsistent with the consignor's express wishes. Consider first Reale v. Sotheby's, Inc, in which a collector consigned his coin collection for sale by auction. ${ }^{56}$ To estimate prices at which the coins might sell, the auction house consulted with a coin expert toward whom the consignor held an intense personal antipathy. Although the consignor claimed to have told the auction house to have no involvement with this particular expert for his sale, the court held that the auction house had no duty to disclose the consultation to the consignor, its principal. The consignment agreement gave the auction house "complete discretion as to ... consulting with any expert," with the consequence that the auction house had no duty either to follow its principal's instructions or

suggest that an auctioneer ... has a fiduciary duty to prospective buyers to mitigate their overbidding"). In general, an auction house acts as an agent only on behalf of consignors, not bidders or purchasers at auction. See Sotheby's, Inc. v. Minor, 2009 WL 3444887 at * 9 (SDNY Oct 26, 2009). And in general an agent breaches its fiduciary duty to its principal "by acting by or on behalf of an adverse party in a transaction connected with the agency relationship." Restatement (Third) of Agency $\S 8.03$.

${ }^{55}$ For a specific example, see Peter Watson, From Manet to Manhattan (Random House 1992) 22.

${ }^{56} 718$ NYS2d 37 (App. Div. 2000). 
to disclose the fact of its noncompliance with them. ${ }^{57}$ Thus, the consignment agreement in Reale had the consequence of relieving the auction house of duties of performance that an agent conventionally owes a principal. ${ }^{58}$

The same ensemble of agreements may also place actions by the auction house outside the boundary of duties that an agent otherwise owes a principal when its actions would breach an agent's duties of loyalty, ${ }^{59}$ as opposed to the duties of performance implicated by Reale. In three relatively recent cases, disputes over an object's authenticity illustrate tensions between an auction house's fiduciary position as the consignor's agent and its rights defined by contract. In all, the court's analysis turns on whether the ensemble of consignment and sale agreements placed the auction house's action outside the scope of its role as consignor's agent.

Situated outside that scope, an auction house's contractual rights may extend to conduct not specified in the consignment agreement and likely not foreseen by most consignors. In Kohler v. Leslie Hindman, Inc., owners of a painting purportedly by Theodore Rousseau consigned it for sale to an auction house under an agreement that obliged the auction house to sell the painting according to the conditions of sale detailed in the auction catalog. ${ }^{60}$ These included a provision that neither the consignors nor the auction house made any warranties of authority and that the painting was sold AS IS, although the catalog also stated that in the best

\footnotetext{
${ }^{57}$ Id at 38 .

${ }^{58}$ See Restatement (Third) of Agency $§ 8.09$ (agent's duty to comply with all lawful instructions received from principal) and $\S 8.11$ (agent's duty to use reasonable effort to provide facts to the principal when agent has reason to know principal would wish to have them).

${ }^{59}$ Restatement (Third) of Agency, like Restatement (Second) of Agency, differentiates duties of loyalty from those termed duties of "performance" in Restatement (Third) and "service and obedience" in Restatement (Second).

${ }^{60} 80$ F3d 1181 ( $7^{\text {th }}$ Cir 1996).
} 
judgment of the auction house, the painting was a Rousseau. After a collector's agent viewed the painting at a pre-auction showing, the agent expressed doubts about the attribution to an auction-house employee. Unable to obtain an authoritative opinion before the auction, the collector agreed with auction-house owner that, if he prevailed in the bidding, he could return the painting if an expert later determined it not to be work of Rousseau. The auction house did not disclose this agreement to its consignor; the collector, who made the highest bid at auction, later returned the painting following an expert's assessment that hands other than Rousseau's had painted it.

By making the side agreement with the collector, the auction house arguably took action beyond the scope of its authority that adversely affected its principal's interests. Moreover, having failed to disclose the fact of the side agreement to its consignor, the auction house arguably withheld material information from its principal; had the consignor known about the side agreement when the auction house reached agreement with the collector, the consignor might have terminated the consignment agreement. By doing so, it would have avoided the taint thereafter associated with the painting. However, an additional provision in the consignment agreement distanced the auction house's actions from the scope of its duties as an agent. The agreement stated that the auction house had "authority as your agent to accept the return and rescind the sale of any property if we at any time in our sole discretion determine that the offering for sale of any property has subjected us and/or you to any liability under a warranty of authenticity. ${ }^{, 61}$ In the court's analysis, if the auction house had sole discretion to determine to rescind a sale, it impliedly had discretion to make a conditional promise to rescind. Only the contractual duty of good faith, as measured by the consignee's subjective judgment would

\footnotetext{
${ }^{61} 80 \mathrm{~F} 3 \mathrm{~d}$ at 1184.
} 
constrain its exercise of discretion, not an overarching duty of loyalty to its consignor's interests. Nor was the auction house under a duty to disclose the conditional rescission agreement to the consignor.

Likewise, in Mickle v. Christie's, Inc., an auction house rescinded the sale of an unsigned painting attributed by both its owners and the auction catalog to Carl Wimar. ${ }^{62}$ The successful bidder at auction refused to pay for the painting and requested rescission, allegedly on the basis of doubts circulating in the trade about the Wimar attribution. The auction house resisted but, consistent with the conditions of sale, agreed that the buyer would obtain the opinions of two experts and that the sale would be rescinded if both agreed the painting was not by Wimar. The auction house rescinded the sale after the expert who originally authenticated the painting expressed a lack of confidence and another expert, agreed to by the buyer, opined that the painting was not Wimar's work. The consignors challenged the auction house's rescission as inconsistent with an agent's duty of "undivided loyalty" to its principal.

In the court's analysis, the auction house's fiduciary duties extended only to "'matters within the scope of [its] agency,",63 and that scope itself "may be defined or modified by agreement between the principal and agent." ${ }^{\text {,64 }}$ The consignment agreement provided that the auction house had no obligation to enforce payment by the buyer and that, in the event of non-payment, in its "sole discretion" the auction house may cancel the sale and return the

\footnotetext{
${ }^{62} 207$ F Supp 2d 237 (SDNY 2002). Carl Wimar was a nineteenth century American painter of note. Id at 239.

${ }^{63}$ Id. at 245, quoting Restatement (Second) of Agency $\S 13$ (1958). Comment a to section 13 states that "[t]he agreement to act on behalf of the principal causes the agent to be a fiduciary, that is, a person having a duty, created by his undertaking, to act primarily for the benefit of another in matters connected with his undertaking."

${ }^{64}$ Id at 245 .
} 
property to its consignor. The agreement, like the agreement in Kohler, also authorized the auction house to rescind the sale and accept the return of the property " at any time if [auction house] in our sole discretion determines that the offering for sale of any Property has subjected or may subject [auction house] and/or Consignor to any liability ....",65 Thus, although in rescinding the auction house acted in its own interests and arguably at odds with those of the consignors, the consignment agreement placed its right to do so outside the scope of its agency and its fiduciary obligation to the consignors.

The same analysis insulates an auction house's exercise of contractual discretion although a successful bidder at auction, who seeks to rescind a completed purchase, arguably is motivated as much by simple buyer's regret as by concerns about the authenticity of the object purchased. In Greenwood v. Koven, the bidder who prevailed at auction with a bid for a pastel purportedly by Georges Braque expressed doubts about its authenticity after paying for it and demanded rescission. ${ }^{66}$ Perhaps coincidentally, her demand for rescission followed a sudden and drastic decline art markets after a long period of rising prices. ${ }^{67}$ The auction house independently sought the opinion of an expert, who refused to confirm the pastel's authenticity. Like the Mickle court, the Greenwood court held that any duty the auction house had to refrain from action that would impair its consignor's interests was modified by the provision in the consignment agreement that gave it sole discretion, including discretion to consult experts.

\subsection{Broader theoretical implications}

These art-auction cases have implications for the theoretical treatment of fiduciary duties as

\footnotetext{
${ }^{65}$ Id at $239-40$.

${ }^{66} 880$ F Supp 186 (SDNY 1995).

${ }^{67}$ See Merryman et al (n 25) 1036.
} 
default rules. The fiduciary duty of loyalty has been characterized as a "sticky" default, one difficult for the parties to abrogate or eliminate from the set of legal rules or standards that govern their relationship. ${ }^{68}$ At least in the context of common-law agency, the stickiness of the fiduciary duty of loyalty co-exists with the ability of principal and agent to agree to define the scope of the agent's undertaking or the agency relationship to give the agent rights to take action that is adverse or otherwise detrimental to the principal's interests. The ensembles of consignment and related agreements in the auction-house cases operate without regard to whether the agent has disclosed material facts to the principal or whether the actions that the agent may take are defined with much specificity. What controls—and unglues an otherwise sticky default rule — is the parties' definition through agreement of the scope of the agent's undertaking on behalf of the principal. This definition can be operative to modify or exclude duties of performance the agent would otherwise owe the principal, as in Reale, and, more controversially, to modify or exclude duties of loyalty by narrowing the scope of conduct to which duties of loyalty apply.

\section{Consent to conduct otherwise in breach}

If an agent's action is not outside the scope of the agency relationship and the duties the agent owes as a consequence of undertaking to act as an agent, the agent's duties to the principal include fiduciary duties of loyalty. These include duties to refrain from acting as or on behalf of an adverse party ${ }^{69}$ and to refrain from competing with the principal and taking action on behalf

\footnotetext{
${ }^{68}$ Sometimes a default proves "sticky" not because the law imposes obstacles to its alteration but because the parties fail to alter the term when doing so would be in their best interests. For discussion of this explanation in connection with shareholders who become employees at will of companies they found, see Deborah A. DeMott, 'Wilkes as an Employment Law Case' (2011) 33 W N Eng L Rev 497.

${ }^{69}$ Restatement (Third) of Agency $\S 8.03$.
} 
of the principal's competitors. ${ }^{70}$ A principal may consent to action that would otherwise breach the agent's duty of loyalty. To be effective, however, consent requires that the principal be in possession of material facts. Effective consent also requires specificity. ${ }^{71}$ In contrast, an agent's duties of performance may be modified "as agreed" with the principal, that is, subject to the terms of the agent's agreement with the principal. ${ }^{72}$ Finally, whether a principal has consented to an agent's conduct is a question of historical fact, not hypothesis. It's not a defense to conduct that breaches a fiduciary duty of loyalty that, had the agent asked for the principal's consent, the principal would have given it, ${ }^{73}$ or that a reasonable person in the principal's position would have consented to the agent's action if asked. In particular, an agent who acts disloyally breaches the agent's fiduciary duty although the principal benefits from the agent's action. Were consent instead defined "hypothetically" - deemed present when the agent's breach turns out to be beneficial for the principal — an agent might be tempted to act disloyally, in the hope that the

${ }^{70}$ Id $\S 8.04$. An agent also breaches a fiduciary duty by acquiring a material benefit, without the principal's consent, in connection with a transaction conducted on the principal's behalf. See text accompanying $\mathrm{n} 32$.

${ }^{71} \mathrm{An}$ analogous development in corporate law treats directors' decisions to make awards of stock-based compensation to themselves as transactions in which the recipients are "interested" if the plan under which the awards are made contains no "meaningful limit" on directors' exercise of discretion, although the corporation's shareholders previously approved the plan. See Seinfeld v. Slager, 2012 WL 2501105 at * 12 (Del Ch June 29, 2012)(emphasis in original). That is, the fact that shareholders agreed ex ante to confer a carte blanche is "insufficient" to bring awards made under the plan within the scope of the business judgment rule, see id., which is especially capacious when applied to compensation-related decisions. As a consequence, the directors in Seinfeld bore the burden of establishing that the amounts they awarded themselves under the plan met a test of "entire fairness," see id. Whether the holding is limited to stock-based compensation for directors or encompasses cash compensation that non-officer directors award themselves for board service is a question that Seinfeld does not address.

${ }^{72}$ Restatement (Third) of Agency $\S 8.08$ (duties of care, competence, and diligence).

${ }^{73}$ See Sirko Harder, 'Is a Defaulting Fiduciary Exculpated By the Principal's Hypothetical Consent?' (2008) 8 Oxford U Commonwealth L J 25, 27. 
eventual outcome could then be proven advantageous to the principal. Shifting the definition of consent from historical fact to hypothesis would undermine the agent's incentives to act loyally and would vitiate the principal's entitlement to loyal action that's created by the fiduciary character of an agency relationship. Likewise, shifting to a hypothetical "reasonable principal" standard would contravene the autonomy of the actual principal in a relationship in which the agent, by definition, acts as an extension of that principal in interactions with third parties. Along the same lines, it's not a defense to common-law fraudulent misrepresentation that a victim would have entered into the transaction induced by fraud had the misrepresentation not been made, so long as the victim justifiably relied on the misrepresentation and her reliance was a substantial factor in determining her course of conduct resulting in loss. ${ }^{74}$ That is, the historical fact that the victim relied on a misrepresentation made by the fraud-feasor is determinative, just as is whether a principal in fact consented to the agent's breach of loyalty.

\subsection{Agents for multiple parties}

In contrast with the consignment cases discussed in Section 2, this section focuses on recent cases in which an agent represented multiple sellers or buyers of the same type of asset, in which consent to an agent's action that would otherwise breach the agent's duties of loyalty may be a complex concept. How consent may be manifested varies with the context and, in some settings it may be justifiable to differentiate between individual agents (i.e. natural persons) and an entity-agent with which individuals are associated as employees or otherwise.

Courts acknowledge that consent may be implied in some circumstances, including ones

\footnotetext{
${ }^{74}$ See Restatement (Second) of Torts $\$ 546 \mathrm{cmt}$. b ("It is not even necessary that he would not have acted or refrained from acting as he did unless he had relied on the misrepresentation....It is enough that the representation has played a substantial part, and so has been a substantial factor, in influencing his decision"); Harder (n 46) 27.
} 
in which an industry's basic business model involves the representation of more than one client whose interests may conflict. ${ }^{75}$ For example, it should be evident to a client of a securities brokerage firm that the broker's other customers may be equally keen to buy (or sell) the same security within the same period of time. How the agent deals with excesses of buy- or sell-side orders may be subject to regulation, but the common law of agency does not itself limit a broker's ability and right to accept competing orders from its customers, unless the broker (and the customers) so agree. Similarly, in Gentieu v. Tony Stone/Images Chicago, Inc., the agent was a photographic stock agency that represented many professional photographers, including the plaintiff, who agreed that the agency would serve as her exclusive licensing representative. ${ }^{76}$ The plaintiff alleged that the agency breached its fiduciary duty to her when it solicited and accepted images of babies — plaintiff's photographic specialty—from other photographers. The court disagreed, noting that "the very nature of the stock photography business requires that the stock agency solicit images on the very same subject so that it can offer clients a menu of images to choose from." ${ }^{, 77}$ Aware of how the stock agency operated, the plaintiff chose it as her exclusive licensing representative, impliedly consenting to the agency's work on behalf of her competitors in the baby-photography genre. To be sure, the plaintiff and the agency could agree that it would represent only her work within this genre, but in return the agency may well demand an increase in its compensation to offset the narrowing of its image menu.

Transactions in residential real estate illustrate additional complexities of consent. Agents

${ }^{75}$ Specifics concerning the legal profession are beyond the scope of this Chapter.

${ }^{76} 255$ F Supp 2d 838 (ND Ill 2003).

${ }^{77}$ Id at 865 (emphasis in original). See also Sun Life Assur Co v. Sun Bancorp, 946 F Supp 2d 182, 189 (D Mass 2012)(actions taken by stock transfer agent are not imputed to each company it deals with; any agency relationship is limited to transactions on behalf of particular company). 
often represent multiple prospective buyers or sellers, as in Gentieu, suggesting that clients' consent may be implied to conduct that's otherwise problematic. Moreover, buyer-side representation in residential real-estate transactions is a relatively novel practice, at least in the United States. Thus, would the requisites of effective consent differ depending on whether an agent represents a prospective seller or a buyer? Separately, when principals interact with employees or associates of a brokerage firm, how intensely does the duty of loyalty apply to the firm as opposed to the individuals who interact with principals?

Consider first a case involving aggrieved prospective sellers. In Sonnenschein v. Douglas Elliman-Gibbons \& Ives, Inc., the plaintiffs listed their condominium for sale with a real-estate broker on an exclusive basis. ${ }^{78}$ With the plaintiffs' consent, the listing broker offered a co-brokerage arrangement to other brokerage firms under terms that assured the co-broker who facilitated a sale of half the commission due the listing broker. A salesperson employed by the defendant co-broker identified potential purchasers for plaintiffs' apartment and plaintiff sent an unsigned sales contract to the potential purchasers' lawyer. However, earlier the same month another sales associate of the same co-broker showed the prospective purchasers another apartment in the same building-one listed exclusively with the co-broker-which they preferred and subsequently purchased. The plaintiffs sued the co-broker, alleging that in breach of its fiduciary duty it induced the prospective purchasers to buy an apartment listed solely with it, allegedly generating a higher commission. The court held the defendant had no duty to refrain from showing other properties to a prospective purchaser even if its relationship to the plaintiffs amounted to one of agency. ${ }^{79}$ Specific agreement between the broker and the owner would be

\footnotetext{
${ }^{78} 96$ NY2d 369 (2001).

${ }^{79}$ Accord, Coldwell Banker Commercial Group v. Camelback Office Park, 156 Ariz 226, 230 $-27-$
} 
necessary to create an exclusive commitment by the broker that would require the broker to decline requests from prospective purchasers to see other properties listed with it. A default rule of exclusive commitment, the court argued, would frustrate both sellers and buyers by limiting their marketing and purchasing opportunities.

In Sonnenschein, as in Gentieu, a principal's consent to conduct by an agent that may otherwise breach the agent's fiduciary duties was implied on the basis of the principal's participation in a market with established practices that are well-known and that serve the interests of most prospective sellers and buyers of the same type of asset. However, the scope of a principal's consent is not boundless. The court notes in Sonnenschein that neither the plaintiffs nor their prospective purchasers considered themselves bound by a purchase contract for the plaintiffs' apartment. ${ }^{80}$ The plaintiffs' implied consent to the defendant's representation of other principals with conflicting interests would not extend to another distinct breach of fiduciary duty, such as the defendant's interference with performance of a contract between a third-party purchaser and the plaintiffs. ${ }^{81}$ As a species of consent (as opposed to "agreement"), implied consent is limited in scope to particular conduct or, at most, conduct that is substantially the same. ${ }^{82}$ A principal's consent to one form of breach of fiduciary duty should not justify the agent's commission of another form of breach. Again, a reference to basic tort-law principles is informative. As the Restatement (Second) of Torts observes, "consent to a fight with fists is not

(1988); McEvoy v. Ginsberg, 345 Mass 733 (1963).

${ }^{80} 96$ NY2d at 376-77.

${ }^{81}$ On tortious interference with contract, see Restatement (Second of Torts) $§ 766$ (1979).

${ }^{82}$ Id. $\S 892 \mathrm{~A}(2)(b)$. 
consent to an act of a very different character, such as biting off a finger ...." ${ }^{, 3}$ Consent in this context does not, in short, operate at a high level of generality.

Buyer-side representation in the real-estate context also occurs in a setting in which prospective buyers are well aware that they may compete with others interested in the same property. In Rivkin v. Century 21 Teran Realty $L L C$, the court applied the reasoning in Sonnenschein to prospective buyers of property who are represented by brokers. ${ }^{84}$ Unless the principal and a brokerage firm agree otherwise, the firm does not breach its fiduciary duty to the principal when individual associates of the firm make offers to purchase property on which the principal has bid, acting on behalf of other prospective buyer-side clients. Nor is the firm obliged to assure that its associates and affiliates do not facilitate offers by prospective purchasers that may compete with the principal's, unless the firm and the principal specifically so agree.

Thus, Rivkin appears to set the default rule at the same point as does Sonnenschein. However, the apparent parallelism is misleading because Rivkin also differentiates the default rule applicable to an individual agent from that applicable to the brokerage firm with which the individual is associated. An individual agent who represents multiple prospective buyers who bid on the same property breaches the agent's fiduciary duty to each unless each the agent makes disclosure to and obtains the consent of each principal. ${ }^{85}$ Why the difference? As the court explains, “[a]n individual buyer's agent acting on behalf of multiple clients bidding on the same property cannot negotiate an optimal purchase price for all of them. The buyers' interests conflict

\footnotetext{
${ }^{83}$ Id. cmt. c.

${ }^{84} 10$ NY3d 344 (2008).

${ }^{85}$ Id at 357.
} 
To be sure, the would-be buyers' interests would also conflict when individual agents associated with the same brokerage firm submit offers to purchase the same property on behalf of their separate clients, but the likelihood that the firm-level conflict will impair loyal representation at the individual-agent level is more attenuated. For one thing, if an individual agent's client does not succeed in purchasing property, the agent receives no commission. Of course, the same distinction between disloyalty at the level of individual agents as opposed to disloyalty at the level of the firm with which the individuals are associated is not universally applicable. For example, the conflict created by an individual lawyer's representation of a client may be imputed to the lawyer's firm and make improper its representation of another client with an adverse interest. ${ }^{87}$

These distinctions have implications for theoretical treatments of fiduciary duties as default rules. Although the cases stem from common situations in which an agent's actions are within the scope of the agent's representative role, consent by the principal to action that otherwise would breach the agent's fiduciary duty is both nuanced and context-dependent. Consent, which may be implied in some circumstances, is operative only within its scope and does not extend or transfer from a consented-to breach of fiduciary duty to another distinct breach, lurking in the background in a fashion comparable to the principal's advance consent through the conferral of authority. ${ }^{88}$ Moreover, as Rivkin illustrates, how courts set the default rule turns on the risks implicit in the situation. At the individual-agent level, unless a prospective

\footnotetext{
${ }^{86}$ Id at 356.

${ }^{87}$ See, e.g., Restatement (Third) of the Law Governing Lawyers $§ 123$ (2000).

${ }^{88}$ On "lurking" consent, see text accompanying n 20.
} 
buyer gives particularized consent and has received disclosure concerning the agent's representation of a competing bidder, the agent's representation of multiple competing principals breaches the agent's fiduciary duties because the risk of compromised loyalty is so evident. On the firm level, default rules contemplate a well-known practice of multiple representations of principals by brokerage firms with no likely reason necessarily to favor one principal over another.

\subsection{Terminal agreements: releases of claims when an agency relationship is at an end}

Temporal limits also define the scope of the duties an agent owes a principal. In particular, following the end of a relationship of agency, the (now-former) agent is free to deal with the (now-former) principal at arms-length unless some basis other than agency imposes fiduciary duties on the former agent. Less straightforwardly, toward the formal conclusion of an agency relationship, the soon-to-be former agent and principal may have dealings or enter into agreements that may be disadvantageous to the principal. When the principal challenges their terms, post-relationship, as breaches of the agent's fiduciary duty, the agent's defense is often that the relationship had deteriorated to the point that the parties dealt as adversaries, which obviated any fiduciary duty that the agent might have otherwise owed the principal. Whether the agent's argument is plausible necessarily turns on specific facts about the parties and their relationship, including the principal's degree of sophistication. In particular, if the principal enters into an agreement that releases claims against the agent stemming from the agent's prior conduct, to the extent the release concerns claims of breach then unknown to the principal it is ineffective if an agency relationship still links the parties; an agent's duties of disclosure encompass all material information, including prior conduct by the agent breaching the agent's 
duties to the principal. ${ }^{89}$ Although it is valuable to enable parties to bring finality to a relationship, including through releases of claims they may assert against each other, ${ }^{90}$ it is important that the perception of adversarial dealings be mutual. ${ }^{91}$

\section{Conclusion: agreement and consent}

As this Chapter demonstrates, within a relationship of common-law agency, the relative “stickiness" of fiduciary duty as a default rule varies. Agency doctrine involves two different kinds of altering rules, that is, necessary and sufficient conditions to vary a default rule. ${ }^{92}$ Through agreement defining the scope of an agent's undertaking or representative role on behalf of the principal, the parties may exclude actions the agent may take from the scope of the undertaking and the agent's fiduciary duties. Separately, through consent, a principal may relieve an agent of liability for conduct that would otherwise constitute a breach of fiduciary duty.

${ }^{89}$ See Merrill Lynch, Pierce, Fenner \& Smith, Inc v. Cheng, 901 F2d 1124 (DC Cir 1990) (broker's duties of disclosure to client encompassed duty to disclose that client had right to reject unauthorized purchases made by broker).

${ }^{90}$ Several recent cases adopt this justification when a release of claims, including those grounded in fraud, accompanies the purchase of an equity interest by one owner from another. See Barr $v$. Dyke, 49 A3d 1280 (Me 2012); Centro Empresarial Cempresa SA v. América Móvil, SAB de CV, 952 NE2d 995 (NY 2011). Both Barr and Centro Empresarial emphasize the parties's sophistication and demonstrable wariness of each other.

${ }^{91}$ See Finn v. Prudential-Bache Secs, Inc, 821 F2d 581, 588 (11 ${ }^{\text {th }}$ Cir 1987)(Brown, J, dissenting)(record on appeal "does not, as required, demonstrate beyond genuine factual controversy at what point [clients] should have known to stop treating [brokerage firm] as their trusted financial advisor"). In Finn, the inexperienced clients' broker likely defrauded them; the broker's employer demanded a release that encompassed all claims, including fraud, as an alternative to immediate liquidation of the clients' account, which the broker had indebted by over $\$ 500,000$. The majority opinion emphasized that the clients were represented at the point of the release by counsel, who later wrote a memo to himself stating he told his clients they "probably" had a securities fraud claim against the firm. Id at 586. The dissent discredits the lawyer's statement as "not made as an historical record of the events" but as a predictable result of an anticipated malpractice claim. Id at 589.

${ }^{92}$ For this terminology, see Ian Ayres, 'Menus Matter' (2006)73 U Chi L Rev 3, 6. 
Consent requires disclosure by the agent to the principal of material facts, plus a manifestation by the principal of willingness that particular conduct occur. Consent thus resembles the application of a fact-specific and multi-variable standard and not the application of a crystalline rule with requisites that can be determined in advance with precision. ${ }^{93}$

Clarity about the distinct roles of agreement and consent has both theoretical and practical value. In the view of the leading English authority on agency law, "[a] too casual failure to recognize the requirements of a fiduciary position, and sometimes a short-sighted assumption that all relevant duties are prescribed in a contract, can be and has been responsible for serious misbehaviour in the financial markets and elsewhere, as is shown by many litigated cases in the last quarter-century." ${ }^{.94}$ In this respect, the relevant formulations in the Restatement (Second) of Agency were less than optimally clear. On the one hand, language introducing the specific sections detailing an agent's duties acknowledged that although an agency relationship "normally involves a contract, it is a special kind of contract, since an agent is not merely a promisor or a promisee but is also a fiduciary. ${ }^{.95}$ On the other hand, most of the specific sections articulating an agent's duties of loyalty began "[u]nless otherwise agreed ...." ${ }^{.96}$ Although the

\footnotetext{
${ }^{93}$ See McDonnell, (n 7) (characterizing duty of loyalty in corporate law as an instance of a "tailored altering rule," customized in application to specific factual circumstances as understood by the court).

${ }^{94}$ Francis MB Reynolds, Bowstead \& Reynolds on Agency $\left(18^{\text {th }}\right.$ edn, Sweet \& Maxwell 2006) 183

${ }^{95}$ Restatement (Second of Agency), Introductory Note to Ch. 13, at 171. The passage continues: "Even specific agreements, however, must be interpreted in light of the principles which are applicable to the relation of principal and agent."
}

${ }^{96}$ See id $\S \S 387,388,389,390,391,393,394,395,396,397 \& 398$. The one exception is section 392 , applicable to an agent who is known to two principals to act for both of them in a transaction between them. Section 392 imposes a duty on the agent to act with fairness to each principal and to disclose to each all facts reasonably believed material to the principal, unless a 
repetition of this phrase, coupled with Restatement (Second)'s silence about its meaning, carried the potential for confusion, ${ }^{97}$ most courts examined agreements between principal and agent closely, placing the burden on the agent to show indicia of consent by the principal to actions within the scope of the agent's representative role that would otherwise contravene the agent's duties of loyalty. ${ }^{98}$ Restatement (Third) of Agency, in contrast, explicitly requires consent by the principal to instances of disloyal conduct within the scope of the agent's role. ${ }^{99}$ In broad outline, its treatment of attempts to alter an agent's fiduciary duty of loyalty corresponds to the pattern identified in the theoretical literature discussed in this paper.

The distinction between agreement and consent has intriguing parallels elsewhere in basic agency doctrine. When a principal confers authority on an agent (or reasonably appears to a third party to have done so), the principal is bound by actions the agent takes within the scope of the agent's actual or apparent authority even though the principal may regret what the agent has done when the principal learns of it; as discussed above, authority constitutes a form of "lurking" or background consent. For example, if the owner of a painting consigns it to an auction house for sale with a low reserve price, the consignor is bound by a sale at or above that price although the consignor comes to believe she set the reserve too low. The creation of actual or apparent authority in an agent, like an agreement, is effective to bind the principal when the agent acts

principal has manifested that he knows such facts or does not wish to know them.

${ }^{97}$ For a recent example, see Greenwood, 880 F Supp at 194 (" $[\mathrm{t}]$ he 'unless otherwise agreed' language appears throughout the Restatement and is clearly meant to allow parties to modify by contract the common law agency principles that would govern their agreement in the absence of an agreement.").

${ }^{98}$ See Restatement (Third) of Agency $\S 8.06$, Reporter's Notes.

${ }^{99}$ Id. $§ 8.06$. 
consistently with it, although the terms of the authority are stated in general terms, for example by a consignment with no minimum reserve price. In contrast, when an agent acts without actual or apparent authority to bind the principal, the principal may become bound — as if the agent had acted with actual authority — by ratifying what the agent has done. Like effective consent, ratification requires specificity because the principal must know what the agent has done. ${ }^{100}$ And ratification, like effective consent, is a matter of historical fact, not hypothesis. A principal ratifies only through action manifesting assent to be bound by the agent's action. Showing that the principal in fact benefitted through the agent's conduct establishes ratification only when the principal knew the material facts and had no independent right to the benefit; under these circumstances, the principal's failure to repudiate the benefit (and the agent's act that generated the benefit) establishes consent. ${ }^{101}$

Finally, the vocabulary of default rules might be applied to dimensions of common-law agency doctrine apart from fiduciary duty. The starting default rule — that only a person's own actions affect that person's legal position — can be changed through the consensual creation of a relationship of agency with another person. Agency law's baseline rule, reflecting the agent's position as the principal's representative, is that the principal is bound only when the agent acts consistently with manifestations of assent to the agent through which the principal furnishes instructions or other indications of the scope of limit of the agent's representative status. A corollary doctrine — apparent authority—holds the principal when the principal's actions lead third parties reasonably to believe that the agent acts as the principal's representative. The baseline rule and its corollary, which limit the extent to which the agent's actions bind the

${ }^{100}$ Restatement (Third) of Agency $\S 4.06$.

${ }^{101} \mathrm{Id} \S 4.01 \mathrm{cmt} \mathrm{f.}$ 
principal to the scope of the agent's actual or apparent authority, operate as "sticky" defaults in much the same fashion as does the fiduciary duty of loyalty. When an agent steps outside the bounds of actual or apparent authority, only ratification with knowledge of the material facts binds the principal. Ratification, like consent to a breach of fiduciary duty, thus requires specificity. Moreover, like consent, whether an act that effects ratification has occurred is a question of historical fact, not hypothesis. Even when the factual basis for showing ratification is a principal's retention of a benefit generated by the agent's unauthorized act, it's requisite that the principal have known the material facts, not that the unaware principal would have ratified the act had the principal known the facts. 